\title{
Studies on the Pyrazine Complexes of Some Diaryltellurium Dihalides
}

\author{
JITENDER KUMAR NARWAL*, SHASHI CHHABRA, \\ RAJESH KUMAR MALIK, SAPANA GARG and K.K. VERMA \\ *JVMGRR College, Department of Chemistry, CharkhiDadri, Haryana, India. \\ Department of Chemistry, Maharshi Dayanand University, Rohtak, India. \\ ${ }^{*}$ Corresponding author Email: jitender.narwal@yahoo.com
}

http://dx.doi.org/10.13005/ojc/290409

(Received: Septembe 01, 2013; Accepted: October 15, 2013)

\begin{abstract}
Nine new Pyrazine Complexes of diaryltelluriumdihalides, $\mathrm{R}_{2} \mathrm{TeX}_{2}$.Pyz $(\mathrm{R}=p$-methoxyphenyl, p-hydroxyphenyl and 3-methyl- 4-hydroxy phenyl; $\mathrm{X}=\mathrm{Cl}, \mathrm{Br}$, I; Pyz = pyrazine) have been prepared by reactions of diaryltelluriumdihalides with pyrazine in 1:1 molar ratio. These complexes have been characterized by elemental analysis, conductance and cryoscopic measurements, infrared and proton magnetic resonance spectral studies. Conductance studies in nitrobenzene, acetone and acetonitrile predict their non-electrolyte type behaviour in these solvents, which is well supported by cryoscopic data in nitrobenzene. IR and ${ }^{1} \mathrm{H}$ NMR studies suggest the unidentate nature of pyrazine in these complexes, involving only one nitrogen atom in coordination. Thus, tellurium in $\mathrm{R}_{2} \mathrm{TeX}_{2} \cdot \mathrm{Pyz}$ complexes attains a coordination number of five probably in a square pyramidal.
\end{abstract}

Key words: Diaryltellurium dihalides, Pyrazine complexes.

\section{INTRODUCTION}

Aryltellurium tryhalides are known to behave as Lewis acids and form molecular complexes with several nitrogen, oxygen and sulphur donor bases. It has been reported ${ }^{1}$ that Lewis acidity of tellurium atom falls significantly on going from $\mathrm{RTeX}_{3}$ to $\mathrm{R}_{2} \mathrm{TeX}_{2}$. Kulkarni and coworkers screened the adducts of a, $a$ ' -bis(3-nitro/amino benzoyl) tellurium dichloride with $\mathrm{N}$ donor bases for biological activity and were found to be effective Ach $E$ inhibiting agents².
ShekharSrivastava and coworkers ${ }^{3}$ have prepared $\mathrm{R}_{2} \mathrm{TeX}_{2}$. L type compounds where $\mathrm{R}=$ benzyl and $L=2,2$ '-bipridyl; 1,10-phenanthroline and neocuproine. In these adducts, donor ligands are coordinated to tellurium atom. In the view of this and in continuation of our earlier work ${ }^{4,5}$ on reactions of various diorganyltelluriumdihalides $\mathrm{R}_{2} \mathrm{TeX}_{2}$ with some $\mathrm{N}$-donor bases we hereby, report the synthesis and characterization of pyrazine complexes of bis(p-hydroxyphenyl), bis(3-methyl-4hydroxyphenyl),bis(p-methoxy phenyl) tellurium(IV) dihalides. 


\section{EXPERIMENTAL}

\section{Materials and Methods}

All the chemicals used were of Analytical Reagents grade. Solvents were purified and dried by conventional methods.

\section{Preparations}

All the preparations have been carried out in a dry conditions under inert atmosphere of dry nitrogen, as the compounds are sensitive to moisture and air.

\section{Preparation of Diaryltellurium(IV) Dihalides}

Bis( $p$-hydroxyphenyl)tellurium dichloride, bis(3-methyl-4-hydroxyphenyl) tellurium dichloride and bis( $p$-methoxyphenyl)tellurium dichloride were obtained by reactions of tellurium tetrachloride with phenol, o-cresol and anisole respectively. The diaryltelluriumdichlorides were converted to corresponding dibromides and diiodides by halogen exchange processes by using $\mathrm{KBr}$ or $\mathrm{KI}$ in dry methanol.

\section{Preparation of Pyrazine Complexes Pyrazine Complexes of Bis(p-hydroxyphenyl) tellurium(IV) Dihalides}

A saturated solution of pyrazine $(0.40$ $\mathrm{gm}, 5.0 \mathrm{mmol})$ in benzene $(\sim 10 \mathrm{ml})$ was added to a saturated solution of $5.0 \mathrm{mmol}$ of $\mathrm{R}_{2} \mathrm{TeX}_{2}(1.92$ $\mathrm{g}, 2.37 \mathrm{~g}, 2.84 \mathrm{~g}$ for chloride, bromide and iodide respectively) in about $20 \mathrm{ml}$ of methanol. The contents were stirred for about $3 \mathrm{~h}$ which resulted in the separation of a dark coloured solid product. This was filtered, extracted with diethyl ether and dried over $\mathrm{P}_{4} \mathrm{O}_{10}$ in vacuum desiccator.

Pyrazine Complexes of Bis(3-methyl-4hydroxyphenyl) tellurium(IV)Dihalides

A saturated solution of pyrazine $(0.40 \mathrm{gm}, 5.0$ $\mathrm{mmol})$ in benzene $(\sim 10 \mathrm{ml})$ was added to a saturated solution of 5.0 mmol of $R_{2} T_{e X}(2.06$ g. 2.51 g. 2.98 $\mathrm{g}$ for chloride, bromide and iodide, respectively) in about $20 \mathrm{ml}$ of dry methanol. The contents were stirred for $4 \mathrm{~h}$. Brown coloured solid product thus obtained was filtered, washed with diethyl ether and dried over $\mathrm{P}_{4} \mathrm{O}_{10}$ in vacuum desiccator.

Pyrazine Complexes of Bis(p-methoxyphenyl) tellurium(IV) Dihalides
A saturated solution of pyrazine $(0.40$ $\mathrm{gm}, 5.0 \mathrm{mmol})$ in benzene $(\sim 10 \mathrm{ml})$ was added to a saturated solution of $5.0 \mathrm{mmol}$ of $\mathrm{R}_{2} \mathrm{TeX}_{2}(2.06$ g. 2.51 g. $2.98 \mathrm{~g}$ for chloride, bromide and iodide respectively) in methanol + chloroform (20:80). The contents were stirred of $4 \mathrm{~h}$. Orange brown solid product obtained was filtered, extracted with diethyl ether and dried over $\mathrm{P}_{4} \mathrm{O}_{10}$ in vacuum desiccators.

\section{Physical studies}

Elemental analysis for Carbon, hydrogen and nitrogen contents were got estimated from Sophisticated Analytical Instrumentation Facility, Punjab University, Chandigarh on a ELEMENTAR VARIO EL III or CARLO ERBA Model 1108. The conductance studies were carried out in acetone, nitrobenzene and acetonitrile on a highly sensitive Systronics Conductivity Bridge Type 305. A dip type cell with smooth platinum electrodes was used. The molecular weights of the complexes of diaryltellurium(IV) dihalides have been determined cryoscopically using purified nitrobenzene as the solvent. A Beckmann's freezing point apparatus is used. Infrared spectra of the complexes of diaryltelluriumdihalides prepared during this course of study have been recorded in the region $4000-400 \mathrm{~cm}^{-1}$ on a SHIMAZDU FTIR-8300 or PERKIN ELMER Model 2000 FTIR Spectrometer using $\mathrm{KBr}$ pellet technique. The spectra were got recorded from Dr. B.R. Ambedkar Centre for Biomedical Research, University of Delhi, Kurukshetra University, Kurukshetra and Sophisticated Analytical Instrumentation Facility, Panjab University, Chandigarh. 'H NMR spectra were recorded on a BRUKER AC-300F operating at $299.9486 \mathrm{MHz}$ and BRUKER AVANCE II 400 NMR spectrometer operating at $400.13 \mathrm{MHz}$. The data were obtained from Sophisticated Analytical instrumentation facility, Punjab University, Chandigarh. The solutions were prepared in deuterated DMSO- $d_{6}$. Spectra were recorded at room temperature immediately after preparing the solution using tetramethylsilane as an internal reference.

\section{RESULTS AND DISCUSSION}

These diaryltelluriumdihalides when reacted with pyrazine give $1: 1$ type complexes, $\mathrm{R}_{2} \mathrm{TeX}_{2} \cdot \mathrm{L}$ as per scheme-1 $\mathrm{R}_{2} \mathrm{TeX}_{2}+\mathrm{Pyz} \quad \mathrm{R}_{2} \mathrm{TeX}_{2} \cdot \mathrm{Pyz}$ 


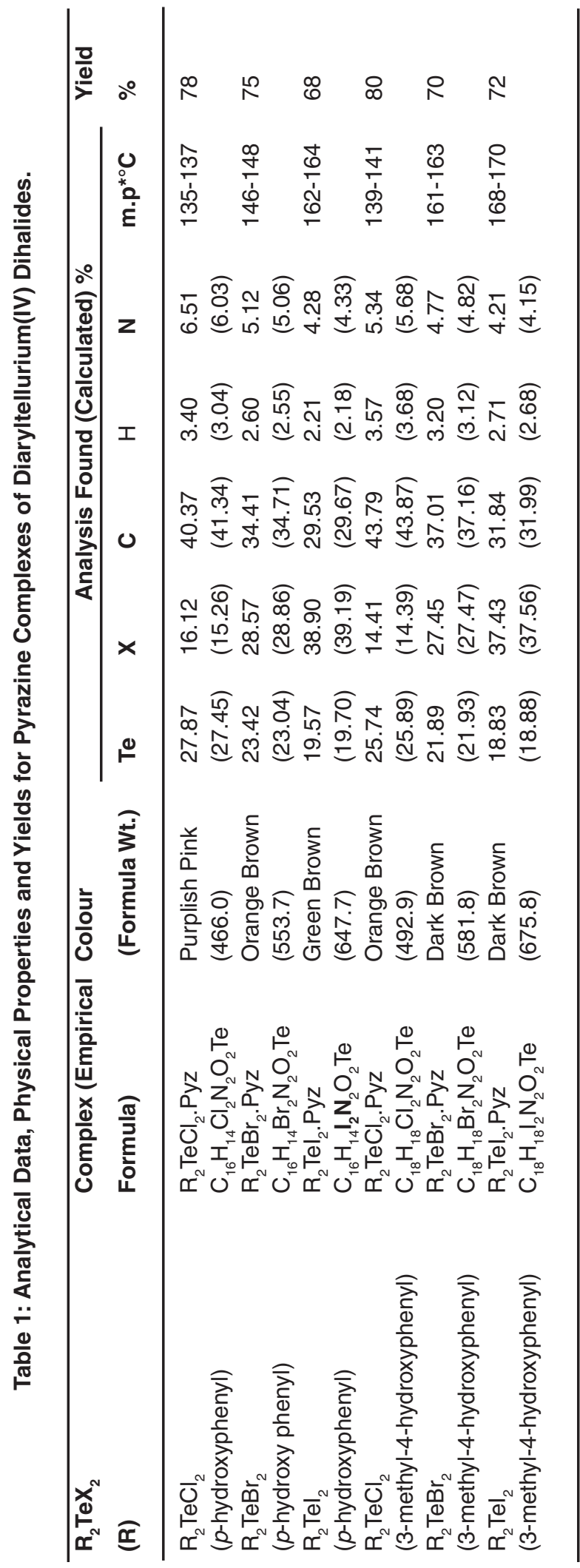




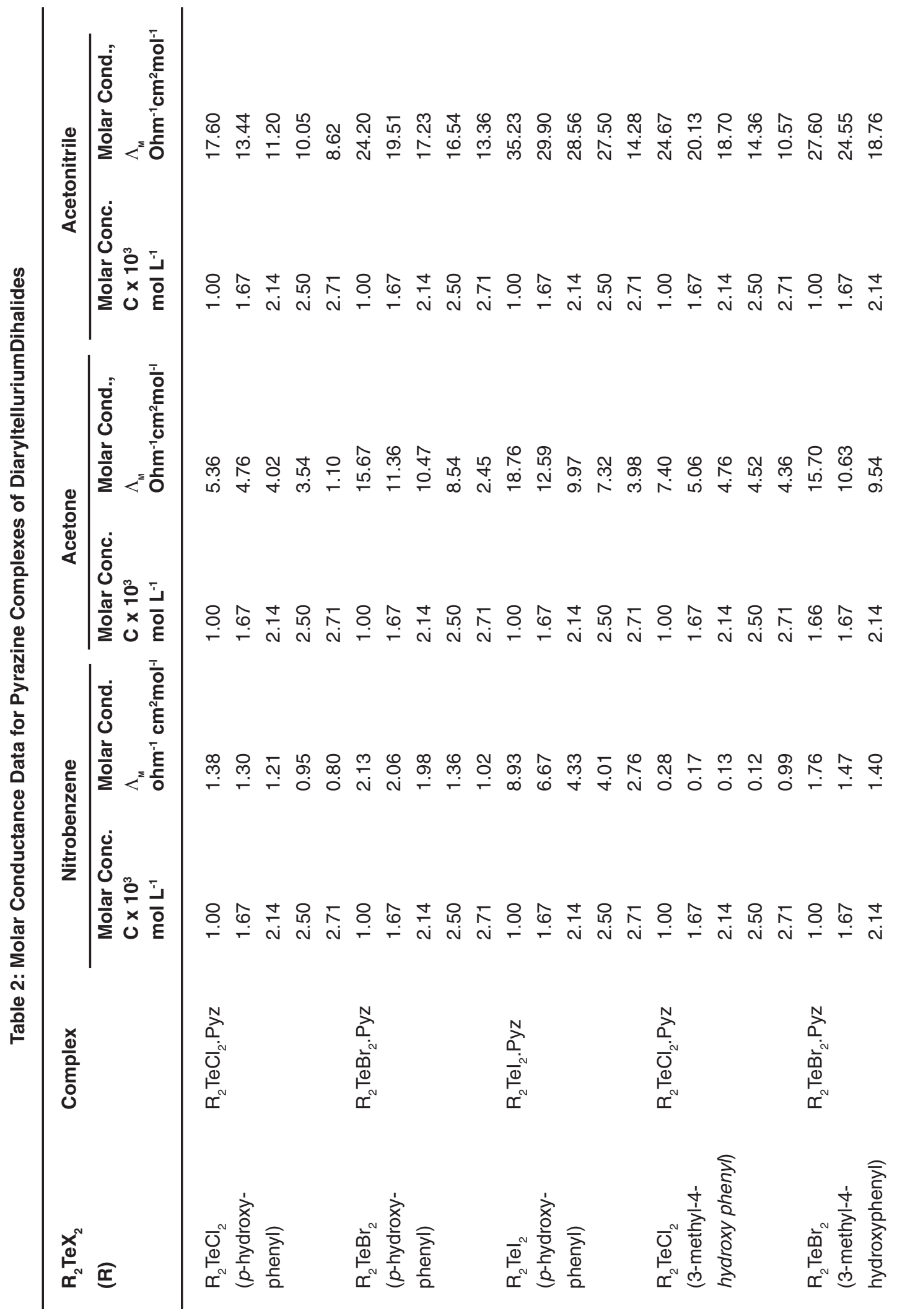




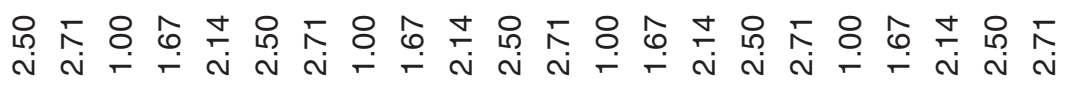

ํ.

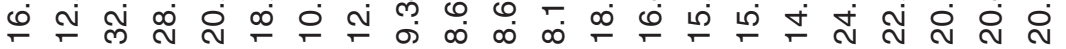

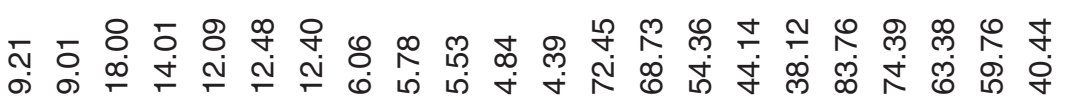

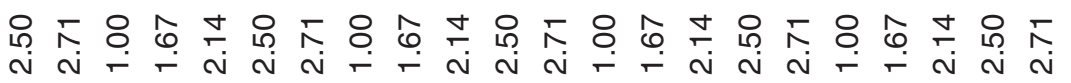

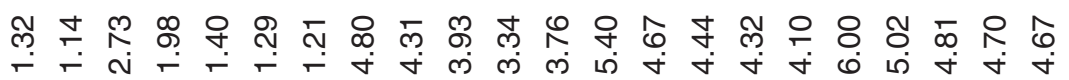

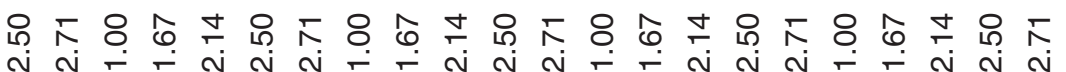
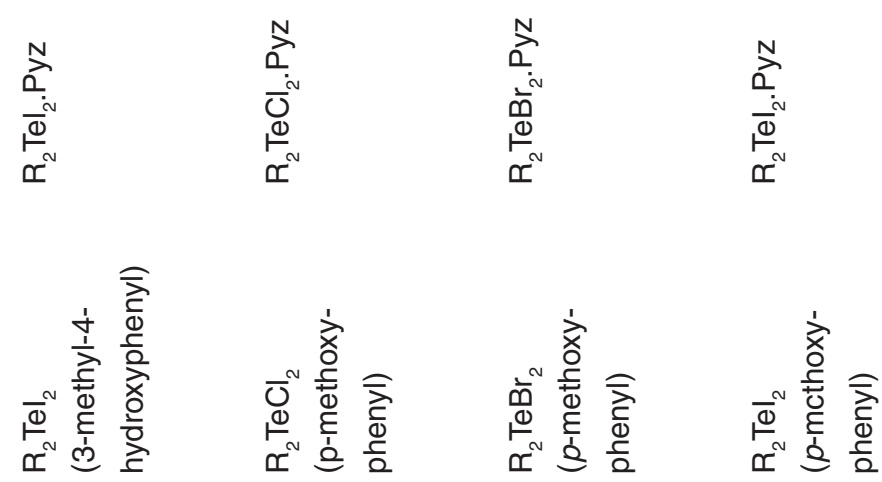

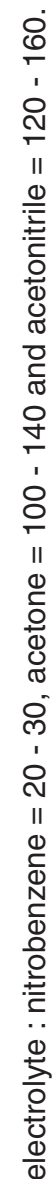


Table 3: Molecular Weight Data for Pyrazine Complexes of Diaryltellurium(IV) Dihalidcs

\begin{tabular}{|c|c|c|c|c|}
\hline $\begin{array}{l}R_{2} \operatorname{TeX}_{2} \\
\text { (R) }\end{array}$ & Complex & $\begin{array}{l}\text { Formula } \\
\text { Weight }\end{array}$ & $\begin{array}{l}\text { Concentration } \\
\text { in mmoles/ } \\
\text { litre of solvent }\end{array}$ & $\begin{array}{l}\text { Molecular } \\
\text { weight } \\
\text { found }\end{array}$ \\
\hline $\begin{array}{l}\mathrm{R}_{2} \mathrm{TeCl}_{2} \\
\text { (p-hydroxyphenyl) }\end{array}$ & $\mathrm{R}_{2} \mathrm{TeCl}_{2} \cdot \mathrm{Pyz}$ & 466.0 & $\begin{array}{l}1.421 \\
2.137 \\
2.953 \\
3.131\end{array}$ & $\begin{array}{l}412.4 \\
439.9 \\
459.8 \\
470.4\end{array}$ \\
\hline $\begin{array}{l}\mathrm{R}_{2} \mathrm{TeBr}_{2} \\
\text { (p-hydroxyphenyl) }\end{array}$ & $\mathrm{R}_{2} \mathrm{TeBr}_{2} \cdot \mathrm{Pyz}$ & 553.7 & $\begin{array}{l}1.377 \\
2.178 \\
2.784 \\
3.182\end{array}$ & $\begin{array}{l}521.7 \\
535.8 \\
546.3 \\
574.6\end{array}$ \\
\hline $\begin{array}{l}\mathrm{R}_{2} \mathrm{Tel}_{2} \\
\text { (p-hydroxyphenyl) }\end{array}$ & $\mathrm{R}_{2} \mathrm{Tel}_{2} \cdot \mathrm{Pyz}$ & 647.7 & $\begin{array}{l}1.276 \\
2.047 \\
3.009 \\
3.921\end{array}$ & $\begin{array}{l}601.4 \\
620.3 \\
628.8 \\
654.6\end{array}$ \\
\hline $\begin{array}{l}\mathrm{R}_{2} \mathrm{TeCl}_{2} \\
\text { (3-methyl-4-hydroxyphenyl) }\end{array}$ & $\mathrm{R}_{2} \mathrm{TeCl}_{2} \cdot \mathrm{Pyz}$ & 492.9 & $\begin{array}{l}1.257 \\
2.193 \\
2.804 \\
3.314\end{array}$ & $\begin{array}{l}453.7 \\
468.9 \\
482.6 \\
501.3\end{array}$ \\
\hline $\begin{array}{l}\mathrm{R}_{2} \mathrm{TeBr}_{2} \\
\text { (3-methyl-4-hydroxy phenyl) }\end{array}$ & $\mathrm{R}_{2} \mathrm{TcBr}_{2} \cdot \mathrm{Pyz}$ & 581.8 & $\begin{array}{l}1.078 \\
1.931 \\
2.487 \\
3.208\end{array}$ & $\begin{array}{l}548.7 \\
560.4 \\
579.9 \\
588.3\end{array}$ \\
\hline $\begin{array}{l}\mathrm{R}_{2} \mathrm{Tel}_{2} \\
\text { (3-methyl -4-hydroxyphenyl) }\end{array}$ & $\mathrm{R}_{2} \mathrm{Tel}_{2} \cdot \mathrm{Pyz}$ & 675.8 & $\begin{array}{l}1.269 \\
2.084 \\
2.978 \\
3.483\end{array}$ & $\begin{array}{l}643.3 \\
657.8 \\
674.3 \\
689.1\end{array}$ \\
\hline $\begin{array}{l}\mathrm{R}_{2} \mathrm{TeCl}_{2} \\
\text { (p-methoxyphenyl) }\end{array}$ & $\mathrm{R}_{2} \mathrm{TeCl}_{2} \cdot \mathrm{Pyz}$ & 492.9 & $\begin{array}{l}1.374 \\
2.038 \\
2.938\end{array}$ & $\begin{array}{l}451.4 \\
477.6 \\
483.3\end{array}$ \\
\hline
\end{tabular}<smiles>c1ccncc1</smiles>

$\mathrm{X}=\mathrm{Cl}, \mathrm{Br}, \mathrm{I}$

Scheme 1. Formation of Pyrazine complexes Where

$\mathrm{R}=p$-hydroxyphenyl, 3-methyl-4hydroxyphenyl, $p$-methoxyphenyl

Pyz $=$ pyrazine
All the compounds were analysed for their tellurium and halogen contents and some for carbon, hydrogen, nitrogen contents as well(results are given in table I). These complexes of diaryltellurium(IV) dihalides are generally coloured, crystalline solid which are fairly stable in dry air. These are generally soluble in polar organic solvents and insoluble in non polar solvents.

\section{Pyz $=$ pyrazine}

The $L_{M}$ values for the pyrazine complexes in nitrobenzene, acetone and acetonitrile are generally much lower than those reported for $1: 1$ electrolytes thus suggesting their non-electrolyte type behaviour in these solvents. Also the $\mathrm{L}_{\mathrm{M}}$ values in a particular 


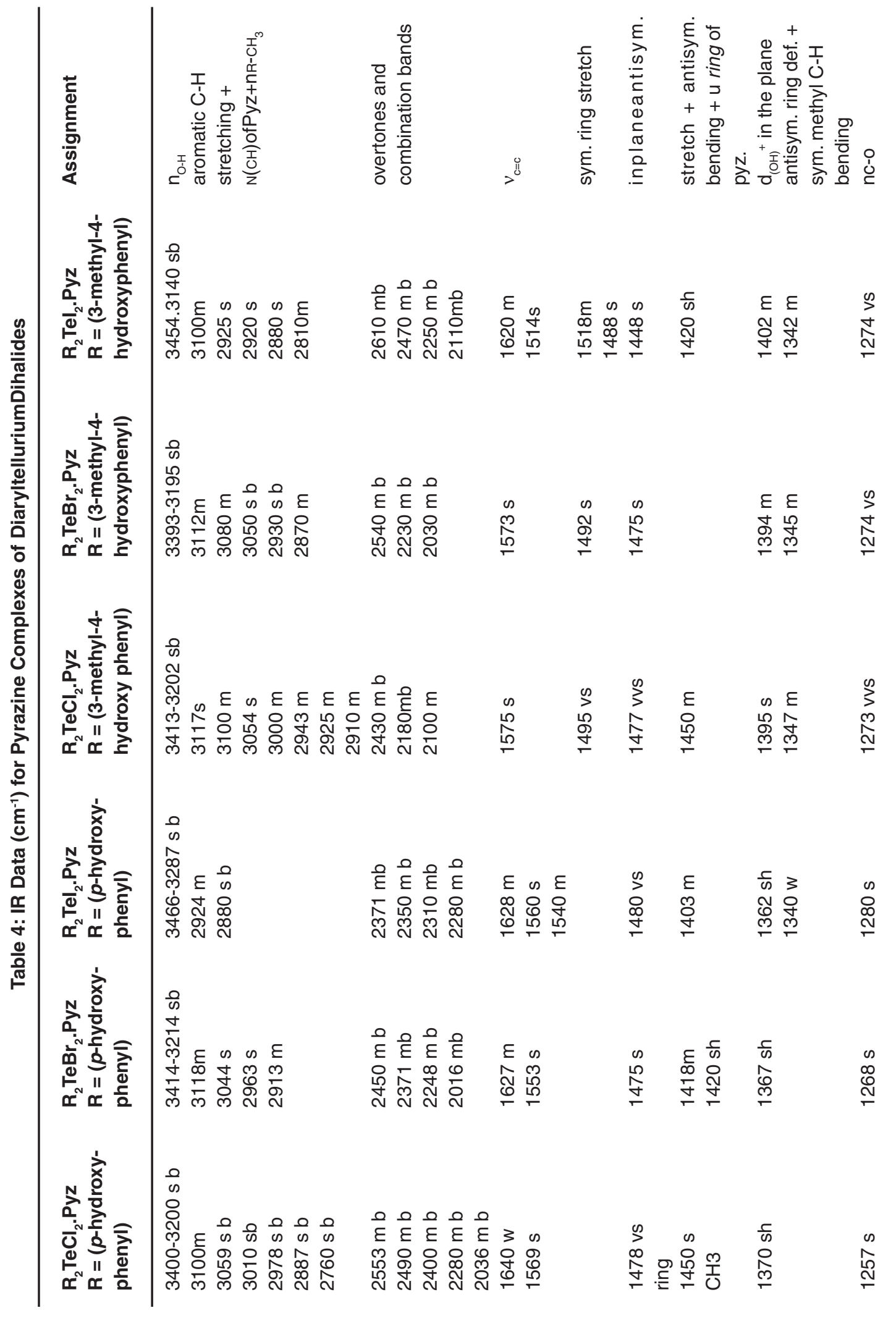



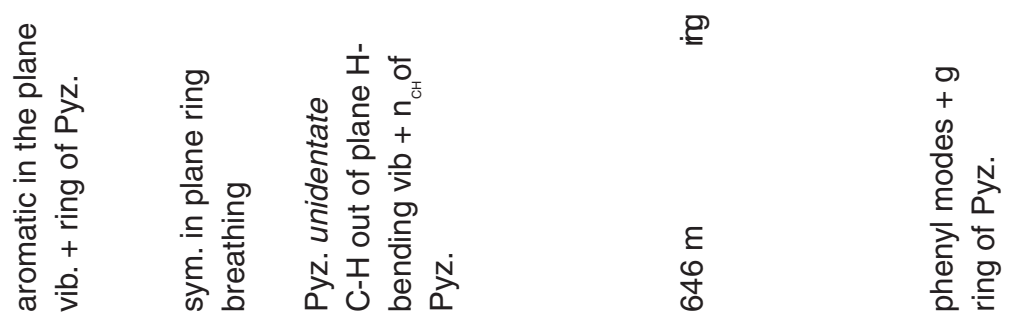

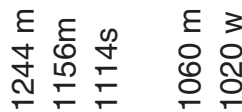

$\varepsilon \omega \backsim \varepsilon \varepsilon$

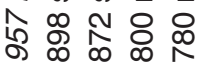

\begin{tabular}{llll}
$\varepsilon$ & E & 3 & 3 \\
0 & 0 & $\infty$ & 0 \\
0 & ป & \multicolumn{1}{c}{}
\end{tabular}

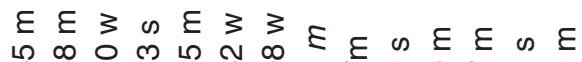

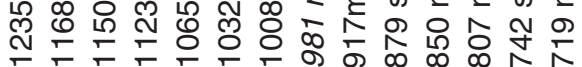

$\varepsilon$
$\stackrel{6}{6}$

E

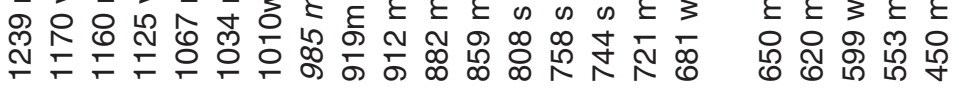

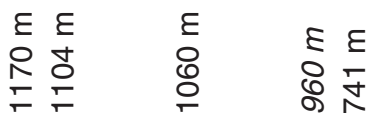

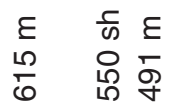

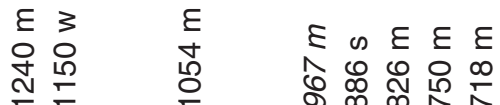

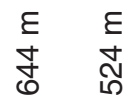

क $थ \varepsilon E \frac{c}{\omega}$

ㄴํㄴ

$\varepsilon \varepsilon \varepsilon \varepsilon$

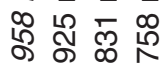

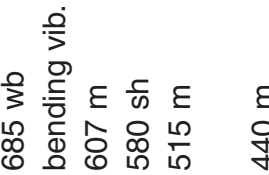

n


Table 5: IR Data $\left(\mathrm{cm}^{-1}\right)$ for Pyrazine Complexes of Bis( $p$-methoxyphenyl)tellurium Dihalides

\begin{tabular}{|c|c|c|c|}
\hline $\mathrm{R}_{2} \mathrm{TeCl}_{2} \cdot \mathrm{Pyz}$ & $\mathrm{R}_{2} \mathrm{TeBr}_{2} \cdot \mathrm{Pyz}$ & $\mathrm{R}_{2} \mathrm{Tel}_{2} \cdot \mathrm{Pyz}$ & Assignment \\
\hline $3200 \mathrm{~s}$ & $3178 \mathrm{~s}$ & $3129 \mathrm{~s}$ & aromatic $\mathrm{C}-\mathrm{H}$ strech $+\mathrm{n}(\mathrm{CH})$ of Pyz. \\
\hline $3075 \mathrm{~m}$ & $3096 \mathrm{~m}$ & $3100 \mathrm{~m}$ & \\
\hline $3010 \mathrm{~m}$ & $2994 \mathrm{~m}$ & $3000 \mathrm{~m}$ & \\
\hline \multicolumn{4}{|l|}{$2900 \mathrm{~m} \mathrm{~b}$} \\
\hline $2175 \mathrm{~m}$ & $2184 \mathrm{~m}$ & $2200 \mathrm{~m}$ & overtones and combination bands \\
\hline $2100 \mathrm{mb}$ & $2093 \mathrm{~m} \mathrm{~b}$ & $2100 \mathrm{mb}$ & \\
\hline 2040 m & $1988 \mathrm{~m}$ & $2000 \mathrm{~m}$ & \\
\hline $1900 \mathrm{~m}$ & $1856 \mathrm{~m}$ & 1975 m & \\
\hline \multirow[t]{3}{*}{$1871 \mathrm{~m}$} & $1743 \mathrm{~m}$ & $1875 \mathrm{~m}$ & \\
\hline & & $1800 \mathrm{~m}$ & \\
\hline & & $1725 \mathrm{~m}$ & \\
\hline $1600 \mathrm{~m}$ & $1586 \mathrm{~s}$ & 1582 vs & skeletal in plane ring \\
\hline 1580 vs & & & stretch \\
\hline $1492 \mathrm{~s}$ & $1498 \mathrm{~s}$ & $1500 \mathrm{~s}$ & $\mathrm{n}$ ring of Pyz \\
\hline \multirow[t]{3}{*}{$1456 \mathrm{~m}$} & $1460 \mathrm{~m}$ & $1487 \mathrm{~s}$ & \\
\hline & $1410 \mathrm{~m}$ & $1457 \mathrm{~m}$ & \\
\hline & & $1420 \mathrm{~m}$ & \\
\hline $1399 \mathrm{~m}$ & $1348 \mathrm{~m}$ & $1300 \mathrm{~s}$ & asym. C-O-C stretch \\
\hline $1301 \mathrm{~s}$ & $1283 \mathrm{~s}$ & $1275 \mathrm{~s}$ & \\
\hline $1255 \mathrm{~s}$ & $1258 \mathrm{~s}$ & 1246 vs & \\
\hline $1175 \mathrm{~s}$ & $1178 s$ & 1179 vs & $\mathrm{g}$ ring of Pyz. + aromatic in the plane vib. + sym \\
\hline $\mathrm{C}-\mathrm{O}-\mathrm{C}$ & $1110 \mathrm{~m}$ & $1107 \mathrm{~m}$ & $1110 \mathrm{~m} \quad$ stretch. \\
\hline $1053 \mathrm{~m}$ & $1024 \mathrm{~s}$ & 1023 vs & \\
\hline 1021 vs & & 1000 w & \\
\hline $965 \mathrm{~s}$ & $953 \mathrm{~s}$ & $957 \mathrm{~s}$ & Pyz. unidentate \\
\hline 815 vs & $835 \mathrm{~s}$ & 880 & $\mathrm{C}-\mathrm{H}$ out of plane $\mathrm{H}$-bending vib $+\mathrm{g}_{\mathrm{CH}}$ of Pyz. \\
\hline \multirow[t]{2}{*}{780 s sh } & & 800 & \\
\hline & & $776 \mathrm{~m}$ & \\
\hline $715 \mathrm{~m}$ & 718 w & $712 \mathrm{~m}$ & out of the plane ring bending vib. \\
\hline $690 \mathrm{w}$ & $640 w$ & $610 w$ & \\
\hline $610 w$ & & $580 w$ & \\
\hline
\end{tabular}

vs $=$ very strong, $\mathrm{s}=$ strong, $\mathrm{sh}=$ shoulder, $\mathrm{m}=$ medium, $\mathrm{w}=$ weak, $\mathrm{vw}=$ very weak, $\mathrm{b}=\mathrm{broad}$

solvent for pyrazine adducts varies in the order. studies as well.

$\mathrm{R}_{2} \mathrm{Tel}_{2} \cdot \mathrm{Pyz}>\mathrm{R}_{2} \mathrm{TeBr}_{2} \cdot \mathrm{Pyz}>\mathrm{R}_{2} \mathrm{TeCl}_{2} \cdot \mathrm{Pyz}$

\section{Cryoscopic measurements}

The cryoscopic data for the pyrazine complexes (Table III) show that molecular weights of these complexes arc quite close to the formula weights, thus suggesting their molecular monomeric nature in nitrobenzene, as predicted by conductance

\section{IR Spectra}

The important IR data $\left(\mathrm{cm}^{-1}\right)$ for pyrazine complexes of diaryltelluriumdihalides are presented in Tables IV and V. The spectra are quite complex and the frequencies from which concrete conclusion can be drawn are listed in the Tables. This may be mentioned that assignments made in the table are 
Table 6: ${ }^{1} \mathrm{H}$ INMR Data (d ppm) for Pyrazine Complexes of DiaryltelluriumDichlorides in DMSO- $d_{6}$.

\begin{tabular}{|c|c|c|c|}
\hline \multirow{2}{*}{$\begin{array}{l}\text { Compound } \\
\mathrm{R}_{2} \mathrm{TeCl}_{2} \cdot \mathrm{Pyz} \\
(\mathrm{R}=p \text {-hydroxyphenyl) }\end{array}$} & \multicolumn{2}{|c|}{ Chemical Shift } & \multirow[t]{2}{*}{ Assignment } \\
\hline & & * & \\
\hline & $2.21^{\mathrm{s}}$ & $(6 \mathrm{H})$ & $-\mathrm{CH}_{3}$ \\
\hline & $6.94^{\mathrm{d}}$ & $(2 \mathrm{H})$ & \\
\hline $\mathrm{R}_{2} \mathrm{TeCl}_{2} \cdot \mathrm{Pyz}$ & & & Phenyl J \\
\hline \multirow[t]{5}{*}{$\left(\mathrm{R}^{2}=3\right.$-methyl-4-hydroxyphenyl) } & $7.50-7.69^{m}$ & $(4 \mathrm{H})$ & $\mathrm{H}_{\mathrm{A}} \& \mathrm{HC}$ \\
\hline & $8.05^{\mathrm{b}}$ & $(2 \mathrm{H})$ & $-\mathrm{OH}$ \\
\hline & $8.61^{\mathrm{s}}$ & $(4 \mathrm{H})$ & Ha (pyrazine) \\
\hline & $3.86^{\mathrm{s}}$ & $(6 \mathrm{H})$ & $-\mathrm{OCH}_{3}$ \\
\hline & $7.02^{\mathrm{d}}$ & $(4 \mathrm{H})$ & \\
\hline R2TeCl2.Pyz & & & Phenyl \\
\hline \multirow[t]{2}{*}{ (R = p-methoxyphenyl) } & $7.94^{\mathrm{d}}$ & $(4 \mathrm{H})$ & $\mathrm{H}_{\mathrm{A}}$ \\
\hline & $8.60^{s}, 8.22^{s}$ & $(4 \mathrm{H})$ & Ha(pyrazine) \\
\hline
\end{tabular}

$\mathrm{s}=$ singlet, $\mathrm{b}=$ broad, $\mathrm{m}=$ multiple, $\mathrm{cm}=$ complex multiple, $\mathrm{d}=$ doublet

* Spectra not well resolved.

based on comparison of spectra of parent $\mathrm{R}_{2} \mathrm{TeX}_{2}$ and pyrazine. The ring vibrations of these may be mixed with each other.

The pyrazine molecule $\left(\mathrm{C}_{4} \mathrm{H}_{4} \mathrm{~N}_{2}\right)$ has the centrosymmetric and planar structure with $\mathrm{D}_{2 \mathrm{~h}}$ symmetry in the vapour and solid phases. The assignments of the infrared spectra of pyrazine in solid $^{6}$, liquid ${ }^{7-8}$ and vapour ${ }^{9-10}$ phases and in solution ${ }^{6,10,11}$ have been reported to be in accord with the $D_{2 h}$ symmetry. The important infrared frequencies which are observed ${ }^{10,11}$ in free pyrazine are 3061 , $3011\left(\mathrm{n}_{\mathrm{CH}}\right), 1483,1412\left(\mathrm{n}_{\text {ring }}\right), 1150\left(\mathrm{n}_{\text {ring }}\right), 1130$ $\left(\mathrm{D}_{\mathrm{CH}}\right)_{9} 1061\left(\mathrm{D}_{\mathrm{cH}}\right), 1019\left(\mathrm{D}_{\text {ring }}\right), 785(\mathrm{ucm})$ and $418\left(\mathrm{n}_{\text {ring }}\right)$. In metal complexes in which both $\mathrm{N}$-atoms of pyrazine are coordinated to two metal atoms, the $D_{2 h}$ symmetry is preserved but is removed in unidentate coordination. Several modes of pyrazinein complexes have upward shift in wave number in comparison with those of free pyrazine. This blue shift in pyrazine bands in the complexes indicates the coordination through $\mathrm{N}$-atom as in pyridine ${ }^{12,13}$. This blue shift in ppyrazine stretching may be due to back bonding from tellurium to pyrazine ring through formation of extensive -bonding.

Lever et a ${ }^{14-17}$ and Kantara ${ }^{18}$ have reported that in complexes where pyrazine is bonded through only one $\mathrm{N}$-atom, the low local symmetry experienced by the pyrazine moiety atoms allows a band to appear in the 950-1000 $\mathrm{cm}^{-1}$ region, which may be taken as an evidence for unidentate nature of pyrazine. This band is reported to be absent in the bridged polymers where pyrazine functions as bidentate ligand. In pyrazine complexes of diaryltellurium(IV) dihalides prepared during this course of study exhibit a medium to strong intensity band in this region, thereby confirming the unidentate nature of pyrazine in these complexes. Thus, tellurium in $\mathrm{R}_{2} \mathrm{TeX}_{2}$.Pyz complexes attains a coordination number of five probably in a square pyramidal environment.

\section{${ }^{1}$ HNMR Spectra}

The ${ }^{1} \mathrm{H}$ NMR data for pyrazine complexes are given in Table VI. The four equivalent protons of free pyrazine which resonate at $8.59^{19} \mathrm{~d} \mathrm{ppm}$ appear at slightly downfield side in $\mathrm{R}_{2} \mathrm{TeCl}_{2} \cdot \mathrm{Pyz}$ complexes due to shifting of electron density from $\mathrm{N}$ of pyrazine to Te of $\mathrm{R}_{2} \mathrm{TeCl}_{2}$. Also in some cases separation between the pyrazine protons has been observed which may be due to monodentate nature of pyrazine. Conversely, the aryl protons of $\mathrm{R}_{2} \mathrm{TeCl}_{2}$ group resonate at upfield side as compared to the parent diaryltellurium dichloride, indicating thereby the shielding of phenyl protons especially those orthoto $\mathrm{TeCl}_{2}$ group. This may be due to an 
increase in electron density at the tellurium atom after accepting the electrons from the pyrazine molecule. Similar shift has also been reported for pyridine complexes ${ }^{20,21}$ of $\mathrm{RTeCl}_{3}$. Thus tellurium in these pyrazine complexes acquires a coordination number of five.

\section{CONCLUSION}

Bis ( $p$-hydroxyphenyl), bis (3-methyl-4hydroxyphenyl) and bis( $p$-methoxyphenyl) tellurium (IV) dichlorides are obtained by direct reaction of tellurium tetrachloride with phenol, o-cresol and anisole respectively.

These diaryltelluriumdihalides have been reacted with pyrazine. The solution behaviour of complexes of diaryl tellurium (IV) dihalides has been investigated by conductance measurement in nitrobenzene, acetone and acetonitrile and cryoscopic measurement in nitrobenzene. The Structural aspects of the complexes of diaryltelluriumdihalides have been investigated conjointly by infrared and proton magneticre-sonance spectroscopy. These complexes of diaryl tellurium (IV) dihalides are generally coloured, crystalline solid which are fairly stable in air. These are generally soluble in polar organic solvents and insoluble in non polar solvents.

\section{ACKNOWLEDGEMENTS}

The authors are thankful to Maharshi Dayanand University, Rohtak for providing the necessary facilities.

\section{REFERENCES}

1. G. Maslakov, E. Gresham, T. A. Hamor, W R. Mcwhinnie, M. C. Perry and N. Saikh, J. Organometal. Chem., 480: 261 (1994).

2. Y.D. Kulkarni, Archana Rani and R. A. Siddiqui, J. Indian Chem. Soc, 69: 353 (1992).

3. ShekharSrivastava, Dilip Kumar Soni and Hari Shankar Gupta, J. Indian Chem. Soc., 73: 255 (1996).

4. K. K. Verma and Sunil Verma, Proc. Indian Council of Chemist 27th Annual Conference, GurukulKangri University, Haridwar, Dec. 2628: paper no. IO-10, p. 23 (2008).

5. K. K. Verma and Sunil Verma, Proc. Indian Council of Chemist 27 $7^{\text {th }}$ Annual Conference, GurukulKangri University, Haridwar, Dec. 2628, paper no. IO-17, p. 27 (2008).

6. G. Sbrana, V. S. Chettino and R. Righini, I Chem. Phys., 59, 2441 (1973).

7. R. C. Loard, A. J. Marson and F. A. Miller, Spectrochim., Acta, 9: 113 (1957).

8. J. Zarembowitch and L. Bokibza-Sebagh, Spectrochim. Acta, A32: 605 (1976).

9. S. Califano. G. Adembri and G. Sbrana, Spectrochim. Acta, 20: 385 (1964).

10. J. F. Arenas, J. J. Lopez-Navarrate, J. C. Otero, J. I. Macros and A. Cardenate, J. Chem. Soc. Faraday Trans., 81: 405 (1985).
11. Z. Kantarci, B. Davarcioglu and C. Bayrak, J. of Inc. Phenom. and Macr. Chem., 39: 115-121 (2001).

12. N. N. Greenwood and K. Wade, J. Chem. Soc, A, 1130 (1960).

13. J. K. Wilmhurst and H. J. Bernsteim, Can. J. Chem., 35: 1183 (1957).

14. B. P. Lever, J. Lewis and R. S. Nyholm, Nature Lond., 189: 58 (1961).

15. B. P. Lever, J. Lewis and R. S. Nyholm, J. Chem. Soc, 1235 (1962).

16. B. P. Lever, J. Lewis and R. S. Nyholm, J. Chem. Soc, 3156 (1963).

17. B. P. Lever, J. Lewis and R. S. Nyholm, J. Chem. Soc, 5042 (1963).

18. H. D. Stidham and J. A. Chandler, J. Inorg. Nucl. Chem., 27: 397-403 (1964).

19. SDBS 3641

20. K. K. Verma, Reena and DayaSoni, Synth. React. Inorg. Met. -Org. Chem., 29: 1033 (1999).

21. Reena, Ph.D. Thesis, M. D. University, Rohtak (1998).

22. Om Prakash, S.A. Iqbal and G. Jacob, Orient J. Chem., 29(3): 1079-1084 (2013).

23. Neeti Rathore and Bal Krishan, Orient. J. Chem., 29(3): 1001-1008 (2012). 